\title{
Nucleophilic Displacements in Supercritical Carbon Dioxide under Phase-Transfer Catalysis Conditions. 2. Effect of Pressure and Kinetics
}

\author{
Alessandro Loris, Alvise Perosa, Maurizio Selva,* and Pietro Tundo* \\ Dipartimento di Scienze Ambientali del 'U niversità Ca' Foscari di Venezia and Consorzio \\ Interuniversitario “La Chimica per I'Ambiente”, Calle Larga S. Marta 2137, 30123 Venezia, I taly \\ selva@univeit; tundop@univeit
}

Received December 10, 2002

\begin{abstract}
The nucleophilic displacement on n-octylmesylate $\left(\mathrm{n}-\mathrm{C}_{8} \mathrm{H}_{17} \mathrm{OSO}_{2} \mathrm{CH}_{3}, \mathbf{1}\right)$ with four different anions $\left(\mathrm{I}^{-}, \mathrm{Br}^{-}, \mathrm{N}_{3}^{-}\right.$, and $\left.\mathrm{SCN}^{-}\right)$is investigated under liquid-supercritical phase-transfer catalysis (LScPTC) conditions, i.e. in a biphase system of supercritical carbon dioxide $\left(\mathrm{scCO}_{2}\right)$ and water, in the presence of both silica supported and conventional onium salts. The $\mathrm{CO}_{2}$ pressure greatly affects the concentration of $\mathbf{1}$ in the sc-phase and plays a major role on its conversion. For example, at 50 ${ }^{\circ} \mathrm{C}$ and with a supported PT-catalyst, the conversion of $\mathbf{1}$ into n-octyl iodide drops by a factor of 5 as the $\mathrm{CO}_{2}$ pressure is increased from 80 to 150 bar, while in the same pressure range, the solubility of n-octylmesylate in $\mathrm{scCO}_{2}$ shows a 6-fold increase, indicating that the reagent is desorbed from the catalyst. Under LSC-PTC conditions, pseudo-first-order kinetic rate constants, evaluated for the investigated reactions, show that the performance of $\mathrm{scCO}_{2}$ as a PTC solvent and the relative nucleophilicity order of the anions $\left(\mathrm{N}_{3}^{-}>\mathrm{I}^{-} \geq \mathrm{Br}^{-}>\mathrm{SCN}^{-}\right)$are comparable to those of toluene and $\mathrm{n}$-heptane. The behavior of conventional phosphonium salts in the $\mathrm{scCO}_{2} / \mathrm{H}_{2} \mathrm{O}$ bi phase system suggests that the reaction may take place either within small droplets of PT-catalyst containing water or in a separate third liquid phase of the PT-catalyst itself.
\end{abstract}

\section{Introduction}

Phase-Transfer Catalysis (PTC) has unquestionable industrial advantages and it offers an exceptional area for fundamental research. In fact, PTC processes are economically competitive since they allow excellent reaction selectivities and substantially quantitative yields under mild conditions (at atmospheric pressure and, often, at room temperature). ${ }^{1}$

However, the growing demand for safer reactions poses the need for alternative solvents with low environmental impact and easier recyclability. Dense $\mathrm{CO}_{2}$ (in both its liquid and supercritical states) is a good candidate: 2 it is intrinsically eco-compatible and possesses physicochemical properties such as a liquidlike density and gaslike diffusivity and viscosity, ${ }^{3}$ which make it an attractive medium for reactions where mass transfer is involved, such as PTC processes. However, a major limitation of $\mathrm{CO}_{2}$ is its modest solvating ability-generally comparable to that of nonpolar media (from hexane to toluene) ${ }^{4}-$ for polar and ionic compounds.

In a previous paper, we faced this problem and set up a new biphasic liquid-supercritical system (LSC-PTC) for

* Corresponding author.

(1) (a) Starks, C. In Phase Transfer Catalysis Principles and Techniques; Academic Press: New York, 1978. (b) Starks, C.; Liotta, C.; Halpern, M. In Phase-Transfer Catalysis: Fundamentals, Applicati ons and Industrial Perspectives; Chapman \& Hall: New York, 1994

(2) Chemical Synthesis Using Supercritical Fluids; J essop, P. G., Leitner W., Eds.; Wiley-VCH: New York, 1999; pp 259-413.

(3) (a) Eckert, C. A.; Van Alsten, J. G.; Stoicos, T. Environ. Sci. Technol. 1986, 20, 319-325. (b) Subramanian, B.; McHugh, M. A. Ind. Eng. Chem. Proc. Dev. 1986, 25, 1-12. (c) Leitner, W. Nature 2000, 405, 129-130.

\section{SCHEME 1. Nucleophilic Displacements under LSc-PTC Conditions}

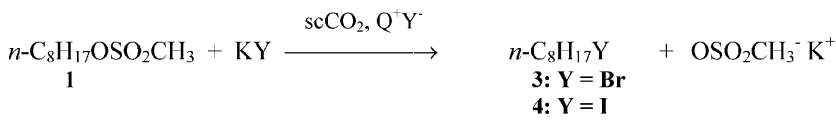

$Q^{+} Y^{-}$salts

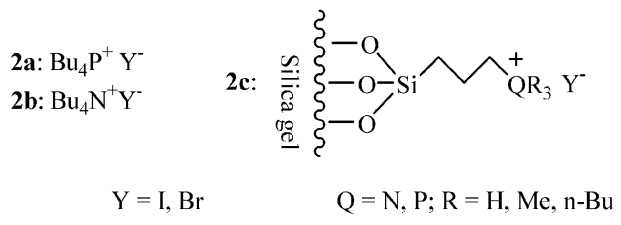

the investigation of nucleophilic displacements on $n$ octylmesylate (1) with halide ions $\left(\mathrm{I}^{-}, \mathrm{Br}^{-}\right)$, in the presence of both silica-supported and conventional onium salts (Scheme 1). ${ }^{5}$

We wish to report here the effects of the supercritical phase on the reaction outcome through (i) measurements of substrate concentration in dense $\mathrm{CO}_{2}$ and (ii) the kinetic analysis of a series of reactions with four different anions $\left(\mathrm{I}^{-}, \mathrm{Br}^{-}, \mathrm{N}_{3}^{-}\right.$, and $\left.\mathrm{SCN}^{-}\right)$.

(4) (a) Croft, M. Y.; Murby, E.J J Wells, R. J . Anal. Chem. 1994, 66 4459. (b) Poliakoff, M.; Howdle, S. Chem. Br. 1995, 31, 118. (c) It should be noted, however, that polarity is only one solvent parameter. The miscibility in $\mathrm{SCCO}_{2}$ is extremely sensitive not only to chemical composition but also to molecular topology. See: Sarbu, T.; Styranec, T.; Beckman, E. J . Nature 2000, 405, 165-168 and references therein.

(5) DeSimone, J .; Selva, M.; Tundo, P. J . Org. Chem. 2001, 66, 4047-4049.

10.1021/j00268308 CCC: $\$ 25.00$ @ 2003 American Chemical Society Published on Web 04/23/2003 


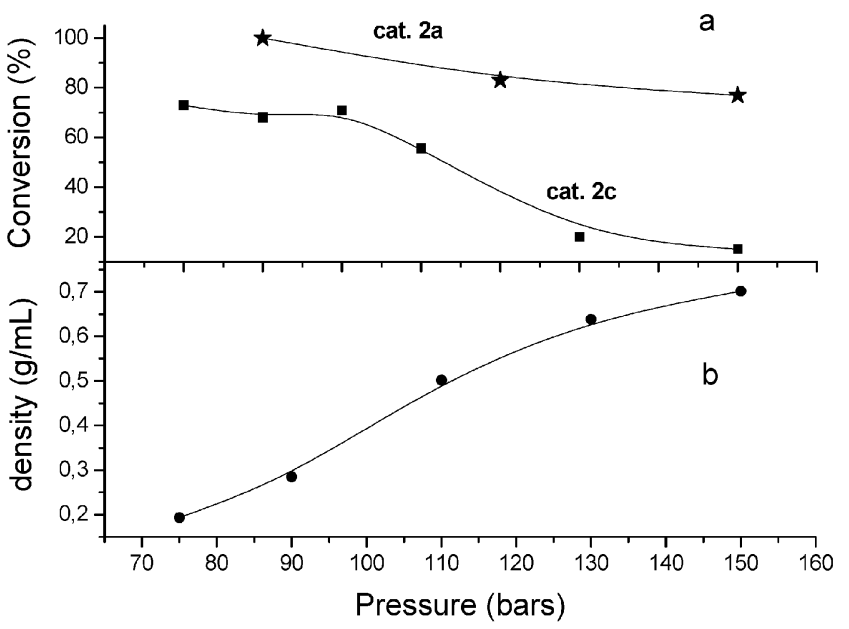

FIGURE 1. (a) The effect of $\mathrm{ScCO}_{2}$ pressure on the conversion of reaction in Scheme 1 carried out with the silica-supported catalyst 2c. Conversion data are averaged over two runs, after $5 \mathrm{~h}$. (b) The density of $\mathrm{scCO}_{2}$ at $50^{\circ} \mathrm{C}$, in the range of $75-150$ bar.

Also, the use of supercritical $\mathrm{CO}_{2}$ as a PTC-solvent is compared (on a kinetic basis) to the classical use of low polarity solvents, such as toluene and n-heptane.

\section{Results and Discussion}

The Pressure Effect. In the dense phase, most of the $\mathrm{CO}_{2}$ properties are affected by its pressure. In particular the density which, at a reduced temperature $\left(T_{r}\right)$ of 1.1 , increases by around $80 \%$ when the reduced pressure $\left(P_{r}\right)$ is augmented from 1 to $3 .{ }^{6}$ Accordingly, a sharp enhancement of the solubility of organic compounds in $\mathrm{CO}_{2}$ is usually observed in the proximity and above the critical point.

Under LSc-PTC conditions, the effect of the $\mathrm{CO}_{2}$ pressure was investigated, using the reaction of Scheme 1 as a model for nucleophilic displacements. Experiments were run at $50{ }^{\circ} \mathrm{C}$ in a stainless steel autoclave loaded with a mixture of compound $\mathbf{1}$, an aqueous solution of $\mathrm{KI}$, and the PT-catalyst (1:KI:2 in a 1:2.5:0.05 molar ratio, respectively). Both catalysts $\mathbf{2 a}$ and $\mathbf{2 c}(\mathrm{Q}=\mathrm{P} ; \mathrm{R}=\mathrm{n}-\mathrm{Bu})$ were used. The pressure of $\mathrm{CO}_{2}$ was varied from 80 to 150 bar and the reaction conversion was measured by GC, after $5 \mathrm{~h}$.

In the case of the supported catalyst $\mathbf{2 c}$, results are reported in Figure 1a (squares), and they are compared with the trend of the $\mathrm{CO}_{2}$ density in the same pressure interval, at $50{ }^{\circ} \mathrm{C}$ (Figure $\left.1 \mathrm{~b}\right){ }^{7}$

As the pressure is enhanced from 80 to 150 bar, the conversion of $\mathbf{1}$ into n-octyl iodide (4) drops from 73\% to $15 \%$, with an overall decrease by a factor of 5 . The $\mathrm{CO}_{2}$ density instead increases about four times in the same pressure range.

A good parallel for this behavior can be found with the silica-promoted Diels-Alder cycloadditions carried out in $\mathrm{SCCO}_{2}$ by Weinstein et al. ${ }^{8}$ Also for these reactions, the

(6) Lucien, F. P.; Foster, N. R. In Chemical Synthesis Using Supercritical Fluids; J essop, P. G., Leitner W., Eds.; Wiley-VCH: New York, 1999; Chapter 1.2, pp 39-53. $\mathrm{T}_{\mathrm{r}}=\mathrm{T} / \mathrm{T}_{\mathrm{c}} ; \mathrm{T}_{\mathrm{c}}=$ critical temperature $=31.1^{\circ} \mathrm{C} ; \mathrm{P}_{\mathrm{r}}=\mathrm{P} / \mathrm{P}_{\mathrm{c}} ; \mathrm{P}_{\mathrm{c}}=$ critical pressure $=73.8 \mathrm{bar}$.

(7) http://webbook.nist.gov.

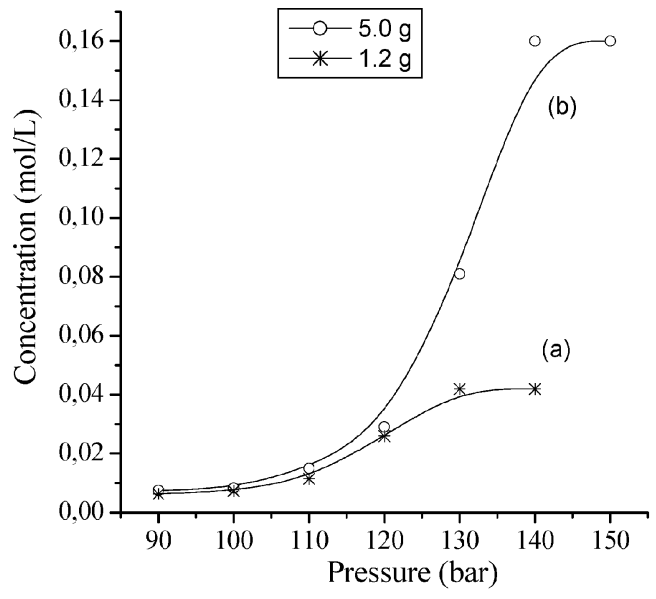

FIGURE 2. Molar concentration of n-octyl mesylate $(0,5.0$ $\mathrm{g} ; *, 1.2 \mathrm{~g})$ in $\mathrm{scCO}_{2}$ at different pressures and at $60^{\circ} \mathrm{C}$.

authors observed that the $\mathrm{CO}_{2}$ pressure had a negative effect on the reaction rate, and they concluded that the result was due to a decreased adsorption of the reagents over the silica surface. As the pressure and hence the density of $\mathrm{sCCO}_{2}$ were augmented, the solubility of reagents in the supercritical phase was enhanced as well, and the rate dropped since reagents were removed from the promoter.

Likewise, in the low-pressure range of Figure 1a, it may be assumed that compound $\mathbf{1}$ is only partially solubilized in $\mathrm{sCCO}_{2}$ so that the high conversion is the result of a favorable partitioning of the reagent on the silica-supported catalyst. Meanwhile, at a higher pressure $\mathbf{1}$ desorbs from the support and the reaction is slowed.

An indirect proof for this reasoning comes from the reaction carried out in the presence of the conventional onium salt 2a (Figure 1a, stars). In the interval pressure of 90-150 bar, the conversion shows only a slight decrease with an overall variation of $\sim 20 \%$. Although the reaction still takes place through the partitioning of $\mathbf{1}$ between the $\mathrm{sCCO}_{2}$ and the onium salt, ${ }^{9}$ the partitioning process does not involve the intermediacy of the silica matrix, so that the pressure effect is more limited. This may account for the different perfomance of catalyst $\mathbf{2 a}$ with respect to $\mathbf{2 c}$, especially in the high-pressure region.

In light of these results, the measure of the concentration of $\mathbf{1}$ in $\mathrm{scCO}_{2}$ at different pressures could give definite support for the interpretation of Figure 1a.

Concentration Measures. n-Octyl mesylate (both 1.2 and $5.0 \mathrm{~g}$ were used) was loaded in a stainless steel autoclave $(150 \mathrm{~mL})$ and pressurized with $\mathrm{CO}_{2}$ in the range of $80-170$ bar, at $60{ }^{\circ} \mathrm{C}$ (details are in the Experimental Section).

Figure 2 reports the results. The molar concentration of 1 in $\mathrm{scCO}_{2}$ is plotted vs the pressure of the supercritical phase. In the pressure region up to 100 bar, the concentration of n-octyl mesylate in $\mathrm{scCO}_{2}$ does not exceed 7 $\mathrm{mmol} / \mathrm{L}$.

(8) Weinstein, R. D.; Renslo, A. R.; Danheiser, R. L.; Tester, J. W. J . Phys. Chem. 1999, 103, 2878-2887.

(9) (a) Dillow, A. K.; J immy Yun, S. L.; Suleiman, D.; Boatright, D. L.; Liotta, C. L.; Eckert, C. A. Ind. Eng. Chem. Res. 1996, 35, 1801. (b) Chandler, K.; Culp, C. W.; Lamb, D. R.; Liotta, C. L.; Eckert, C. A Ind. Eng. Chem. Res. 1998, 37, 3252-3259. 

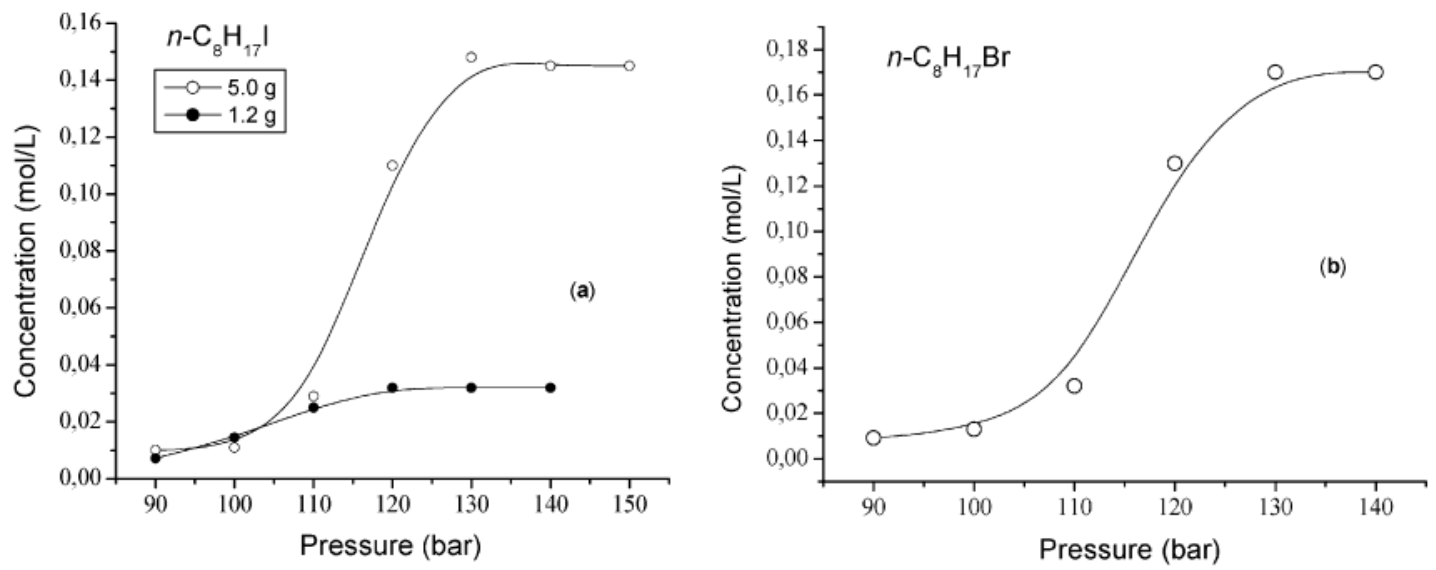

FIGURE 3. Pressure versus concentration plots at $T=60^{\circ} \mathrm{C}$ : (a) concentration of $\mathrm{n}$-octyl iodide $(0,5.0 \mathrm{~g} ; \bullet, 1.2 \mathrm{~g})$ in scCO $\mathrm{sc}_{2}$ at different pressures; (b) concentration of n-octyl bromide $(\mathrm{O}, 5.0 \mathrm{~g})$ in $\mathrm{ScCO}_{2}$ at different pressures.

As the $\mathrm{CO}_{2}$ pressure is increased over 110 bar, the concentration curve a (1.2 g of substrate, stars) has a steep enhancement and between 130 and 140 bar it reaches a plateau of $4.1 \times 10^{-2} \mathrm{~mol} / \mathrm{L}$. A similar behavior is observed when $5.0 \mathrm{~g}$ of $\mathrm{n}$-octyl mesylate are used (open circles, curve b). The concentration curves $a$ and $b$ show a very good overlap until pressures of 120 bar. Then, curve b goes up, and at 140 bar it reaches a maximum of about $0.16 \mathrm{~mol} / \mathrm{L}$. The plateaus of both curves match exactly the values expected for the complete solubilization of $\mathbf{1}$.

At $60{ }^{\circ} \mathrm{C}$, the $\mathrm{CO}_{2}$ pressure has a threshold value of 130-140 bar below which the concentration of the substrate in $\mathrm{ScCO}_{2}$ rapidly falls (to only $4 \%$ of the initial $5.0 \mathrm{~g}$, for pressure drops of $40 \mathrm{bar}$; curve b).

Importantly, these concentration trends validate the initial hypothesis: as Figure 2 is a good mirror image of Figure 1a (cat. 2c), a clear dependence of the reaction conversion on the partioning of the reagent between $\mathrm{scCO}_{2}$ and the silica-supported catalyst can be inferred.

The effect of the $\mathrm{CO}_{2}$ pressure was examined also for the product of the reaction $\left(n-\mathrm{C}_{8} \mathrm{H}_{17} \mathrm{l}\right)$, as well as for bromooctane. Experiments were run at $60{ }^{\circ} \mathrm{C}$, as described for n-octyl mesylate. Results are reported in Figure 3.

The behavior of both halides in $\mathrm{scCO}_{2}$ is similar to that of $\mathbf{1}$. However, it should be noted that the maxima of curves $3 a\left(n-C_{8} \mathrm{H}_{17} \mathrm{l}\right)$ and $3 \mathrm{~b}\left(\mathrm{n}-\mathrm{C}_{8} \mathrm{H}_{17} \mathrm{Br}\right)$ appear slightly shifted to a lower pressure (120-130 bar) with respect to the sulfonate ester (130-140 bar, Figure 2). The higher polarity of this latter compound may account for the difference.

The results of Figures 2-3 not only offer a good explanation for the effect of the $\mathrm{CO}_{2}$ pressure on the reaction conversion, but even more importantly, they indicate that under LSc-PTC conditions, the supercritical $\mathrm{CO}_{2}$ phase acts as a solvent only at a density above 0.5 $\mathrm{g} / \mathrm{mL}\left(\mathrm{P} \geq 130\right.$ bar at $\left.60^{\circ} \mathrm{C}\right)$.

The Kinetic Investigation. Under LSC-PTC conditions, a preliminary kinetic investigation of nucleophilic displacements on $\mathbf{1}$ was carried out with catalyst $\mathbf{2 a}$ ( $\mathrm{n}$ $\left.\mathrm{Bu}_{4} \mathrm{P}^{+} \mathrm{Br}^{-}\right)$, which was more efficient and less sensitive to pressure effects than the silica-supported onium salt. Compound $\mathbf{2 a}$ was immiscible with $\mathrm{SCCO}_{2} \cdot{ }^{10}$

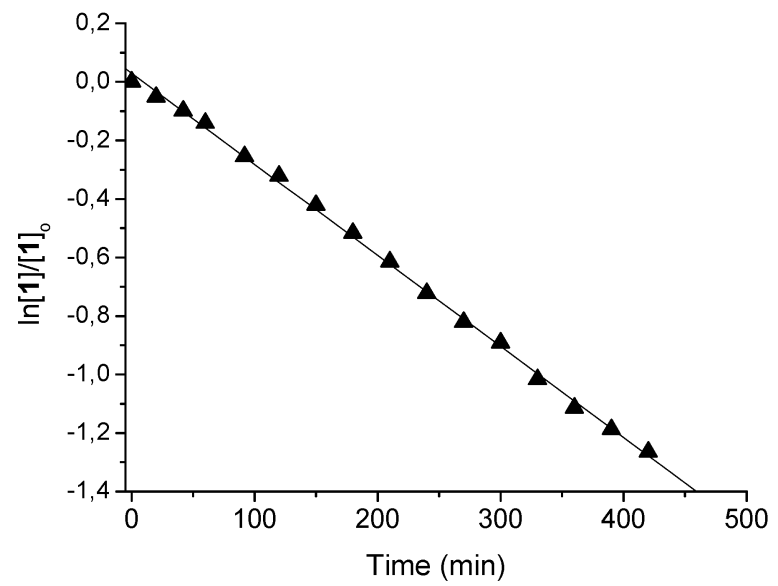

FIGURE 4. The reaction of $\mathrm{n}$-octyl mesylate with $\mathrm{KI}$ : firstorder rate constant plot for the reagent. [1a] and [1a]: concentration of $\mathbf{1}$ at $t=0$ and at a later time $t$.

Initial experiments were run at $60^{\circ} \mathrm{C}$, in a stainless steel autoclave $(90 \mathrm{~mL})$ loaded with a mixture of compound $\mathbf{1}$, an aqueous solution of $\mathrm{KI}$ (or $\mathrm{KBr}$ ), and the catalyst $\mathbf{2 a}$ [1:KI (or $\mathrm{KBr}$ ):2a in a 1:2.5:0.05 molar ratio, respectively]. A pressure of 160 bar was held throughout the reaction $\left(\mathrm{d}_{\mathrm{CO}_{2}}=0.64 \mathrm{~g} / \mathrm{mL}\right)$, which was followed by GC and GC/MS.

In the case of the reaction with aq $\mathrm{KI}$, results are reported in Figure 4.

During both reactions with $\mathrm{KI}$ and $\mathrm{KBr}$, the concentration (determined by GC) of the sulfonate ester fits the expression In $[\mathbf{1} \mathbf{a}] /[\mathbf{1} \mathbf{a}]_{\mathrm{o}}=\mathrm{k}_{\mathrm{t}}\left([\mathbf{1} \mathbf{a}]_{\mathrm{o}}\right.$ and $\left.[\mathbf{1} \mathbf{a}]\right)$. This behavior, in agreement with the general mechanism proposed by Starks for II-PTC processes, ${ }^{1,11}$ allows the calculation of pseudo-first-order rate constants $\mathrm{k}_{\mathrm{obs}}$ of $3.11 \times 10^{-3}$ $\mathrm{min}^{-1}\left(\mathrm{KI}\right.$, slope of Figure 4) and $2.05 \times 10^{-3} \mathrm{~min}^{-1}(\mathrm{KBr})$ for the disappearance of the substrate. ${ }^{12}$

A second set of experiments was then carried out with the same procedure at $70{ }^{\circ} \mathrm{C}$ and under 180 bar of $\mathrm{CO}_{2}$

(10) Onium salts are virtually insoluble in $\mathrm{scCO}_{2}$; ref 9a reported a solubility of $0.21 \mathrm{mmol} / \mathrm{L}$ for tetraheptylammonium bromide in $\mathrm{scCO}_{2}$ (204 bar, $50{ }^{\circ} \mathrm{C}$ ) in the presence of acetone (5\%) as a cosolvent.

(11) (a) Starks, C. M. J . Am. Chem. Soc. 1971, 93, 195. (b) Starks, C. M.; Owen, R. M. J . Am. Chem. Soc. 1973, 95, 3613.

(12) Since an excess of the reactant salt is used, a pseudo-first-order rate constant is considered.

4048 J . Org. Chem., Vol. 68, No. 10, 2003 


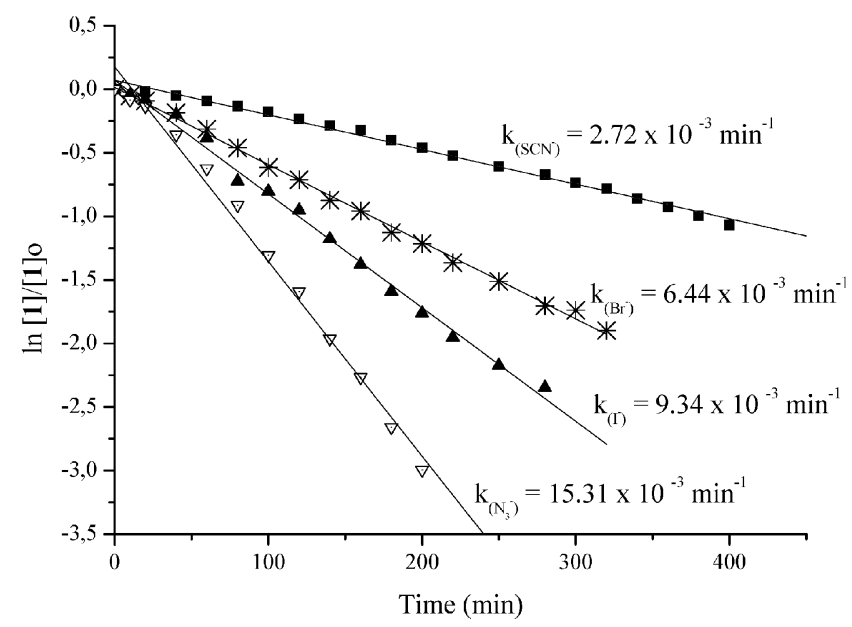

FIGURE 5. $k_{o b s}$ for the reaction of n-octyl mesylate (1) with aq $\mathrm{KX}\left[\mathrm{X}=\operatorname{SCN}(\boldsymbol{\square}), \operatorname{Br}(*), \mathrm{I}(\boldsymbol{\Delta})\right.$, and $\left.\mathrm{N}_{3}(\nabla)\right]$ at $70^{\circ} \mathrm{C}$ and 180 bar.

$\left(\mathrm{d}_{\mathrm{CO}_{2}}=0.61 \mathrm{~g} / \mathrm{mL}\right)$ : compound $\mathbf{1}$ was made to react with aqueous solutions $(4.8 \mathrm{M}, 7.5 \mathrm{~mL})$ of four different potassium salts $\mathrm{KX}\left(\mathrm{X}=\mathrm{I}, \mathrm{Br}, \mathrm{N}_{3}\right.$, and $\left.\mathrm{SCN}\right)$ and the catalyst 2a [1:KX:2a in a 1:2.5:0.05 molar ratio, respectively]. ${ }^{13}$

As for the previous tests, linear logarithmic plots of the concentration of the substrate with time $\left[\ln [\mathbf{1 a}] /[\mathbf{1} \mathbf{a}]_{\text {o }}\right.$ $\left.=\mathrm{k}_{\mathrm{t}}\right]$ were obtained for the reaction of $\mathbf{1}$ with all the examined anions. Results are reported in Figure 5, where $\mathrm{k}_{\mathrm{obs}}($ (slope) is shown for each anion.

The overall scale of relative nucleophilicity of anions is in the order of Scheme 2,14 and it is in agreement with the one reported by Montanari et al. ${ }^{15}$ for the reaction of n-octyl mesylate with the same nucleophiles carried out in a biphasic water/chlorobenzene system and in the presence of $\mathrm{C}_{16} \mathrm{H}_{33} \mathrm{PBu}_{3}{ }^{+} \mathrm{Y}^{-}\left(\mathrm{Y}=\mathrm{N}_{3}{ }^{-}, \mathrm{I}^{-}, \mathrm{Br}^{-}\right.$, and $\left.\mathrm{SCN}^{-}\right)$ as a PT-catalyst. It was demonstrated that the reactivity of anions was due to their hydration shells whose size was in turn related to the size of the nucleophile for the sequence of halide ions $\left(\mathrm{I}^{-}\right.$and $\left.\mathrm{Br}^{-}\right)$, and to the charge dispersion for the $\mathrm{N}_{3}{ }^{-}$and $\mathrm{SCN}^{-}$ions. ${ }^{15 b}$ Moreover, the authors claimed that the highest reaction rates were achieved in the presence of apolar solvents where the anion solvation was the poorest.

Although these considerations could fit also our LScsystem, a comparison between $\mathrm{scCO}_{2}$ and conventional nonpolar media was necessary to understand the effect of the supercritical $\mathrm{CO}_{2}$ phase as a PT-solvent. Solutions of n-octylmethane sulfonate $(0.17 \mathrm{M}, 82.5 \mathrm{~mL})$ in either n-heptane or toluene were made to react at $70^{\circ} \mathrm{C}$, with aqueous solutions $(4.8 \mathrm{M}, 7.5 \mathrm{~mL})$ of $\mathrm{KX}$ salts $(X=\mathrm{I}, \mathrm{Br}$, $\mathrm{N}_{3}$, and $\mathrm{SCN}$ ) in the presence of the catalyst $\mathbf{2 a}[\mathbf{1}: \mathrm{KX}$ :

(13) Under LSc-PTC conditions, some anions (i.e. SCN ${ }^{-}$) appeared quite unreactive. A higher temperature $\left(70^{\circ} \mathrm{C}\right)$ was then necessary. Accordingly, the $\mathrm{CO}_{2}$ pressure was increased (180 bar) to achieve a medium density comparable to that of previous experiments at $60^{\circ} \mathrm{C}$ (see Figure 4).

(14) The solubility (if any) of the catalyst $2 \mathrm{a}$ in $\mathrm{scCO}_{2}$ was not known (ref 10), neither was it determined by us. However, since all reactions of Figure 5 were run at $70{ }^{\circ} \mathrm{C}$ and $180 \mathrm{bar}$, and most of all, using aqueous solutions of identical anion concentrations, corrections of $k_{o b s}$ to account for the catalyst concentration may not be influential.

(15) (a) Landini, D.; Maia, A. M.; Montanari, F.; Pirisi, M. J . Chem. Soc., Chem. Commun. 1975, 950. (b) Landini, D.; Maia, A. M.; Montanari, F. J . Am. Chem. Soc. 1978, 100, 2796.
SCHEME 2. The Scale of Reactivity for Some Anions under LSc-PTC Conditions

$$
\mathrm{N}_{3}^{-}>\mathrm{I}^{-} \geq \mathrm{Br}^{-}>\mathrm{SCN}^{-}
$$

TABLE 1. Pseudo-First-Order $\mathrm{k}_{\mathrm{obs}}$ for the Disappearance of $\mathbf{n}$-Octylmethane Sulfonate in the Reaction with aq KX Salts at $70^{\circ} \mathrm{C}$, under Both II- and LSc-Conditions

\begin{tabular}{clccr}
\hline & & \multicolumn{3}{c}{$\mathrm{k}_{\mathrm{obs}} \times 10^{-3}\left(\mathrm{~min}^{-1}\right)$} \\
\cline { 3 - 5 } entry & anion & $\mathrm{n}$-heptane & toluene & $\mathrm{scCO}_{2}$ \\
\hline 1 & $\mathrm{~N}_{3}^{-}$ & 14.36 & 24.53 & 15.31 \\
2 & $\mathrm{I}^{-}$ & 8.90 & 6.13 & 9.34 \\
3 & $\mathrm{Br}^{-}$ & 5.81 & 6.28 & 6.44 \\
4 & $\mathrm{SCN}^{-}$ & 1.90 & 1.29 & 2.72 \\
\hline
\end{tabular}

2a in a 1:2.5:0.05 molar ratio, respectively]. In all cases, $\mathrm{k}_{\mathrm{obs}}$ of pseudo-first-order were measured for the disappearance of the substrate.

Results are reported in Table 1.

Although a direct kinetic comparison of the solvent effect is not possible, ${ }^{16}$ it should be noted that the reactivity scale underlined in Scheme 2 has a general validity for each of three solvents investigated.

Under biphasic water/supercritical conditions, $\mathrm{CO}_{2}$ appeared a good PT-solvent: within limits, its behavior resembled that of apolar C7-C8 aliphatic or aromatic hydrocarbons.

However, a relevant point still needed to be clarified.

Under II-PTC conditions, a well-known concept is that the efficacy of onium salts as PT-catalysts largely depends on their organophilicity. ${ }^{1,17}$ Lipophilic salts have small but not negligible extraction constants $\left(E_{Q x}{ }^{18}\right)$ in bi phasic water/apolar solvent systems: for instance, in a water/chlorobenzene biphase, an $\mathrm{E}_{\mathrm{Qx}}$ of 0.1 was reported for $\mathrm{Bu}_{4} \mathrm{~N}^{+} \mathrm{Br}^{-} .19$

By contrast, although onium salts were substantially insol uble in $\mathrm{SCCO}_{2}$, LSc-reactions yielded results similar to those of II-processes carried out in toluene or nheptane.

To understand how the onium salt promotes the reaction, the following experiment was carried out. An autoclave ( $150 \mathrm{~mL}$ ) was loaded with an aqueous solution of the catalyst $2 \mathbf{a}\left(9.6 \times 10^{-3} \mathrm{M}, 25 \mathrm{~mL}\right)$, heated at $70^{\circ} \mathrm{C}$ under stirring, and finally pressurized with $\mathrm{CO}_{2}$ at 180 bar. After $30 \mathrm{~min}$, stirring was stopped and the mixture was allowed to settle. Known volumes of both the

(16) Second-order rate constants expressed as $k_{\text {obs }} /\left[\mathrm{Bu}_{4} \mathrm{P}^{+} \mathrm{Br}^{-}\right]_{\text {org }}$ should be considered to account for the actual concentration of the PT. catalyst in each of three solvents. However, no data were available for $\left[\mathrm{Bu}_{4} \mathrm{P}^{+} \mathrm{Br}^{-}\right]_{\mathrm{scCO}}$ (see also ref 10 and footnote 14).

(17) (a) Dehmlov, E. V.; Dehmlov, S. S. In PhaseTransfer Catalysis, 3rd ed.; VCH Publishers: New York, 1993. (b) Phase Transfer Catalysis; Halpern, M. E., Ed.; ACS Symp. Series no. 659; American Chemical Society: Washington, DC, 1997.

(18) Bar, R.; Karpuj-Bar, L.; Sasson, Y.; Blum, J . Anal. Chim. Acta 1983, 154, 203. $\mathrm{E}_{\mathrm{QX}}$ is the ratio of concentration of the onium salt between the organic and the aqueous phases $\left\{\mathrm{E}_{\mathrm{QX}}=\left[\mathrm{Q}^{+} \mathrm{X}^{-}\right]_{\text {org }} /\left[\mathrm{Q}^{+}\right]_{\mathrm{aq}}{ }^{-}\right.$ $\left.\left[\mathrm{Y}^{-}\right]_{\mathrm{aq}}\right\}$.

(19) Montanari, F.; Landini, D.; Rolla, F. Top. Curr. Chem. 1982, 101,147 . Also, ref $13 \mathrm{~b}$ reported that in a water/chlorobenzene system $(1: 0.75 \mathrm{v} / \mathrm{v})$, the reaction of $\mathrm{n}$-octylmethane sulfonate with aq $\mathrm{KBr}$ yielded $k_{\text {obs }}=10.4 \times 10^{5}$ and $0.24 \times 10^{5} \mathrm{~s}^{-1}$ in the presence of $\mathrm{Bu}_{4} \mathrm{P}^{+} \mathrm{Br}^{-}$ (2a) and $\mathrm{Pr}_{4} \mathrm{~N}^{+} \mathrm{Br}^{-}$, respectively. Although a salting-out effect took place, the percent of the two catalysts in the organic phase was 97 and 2.5\% (Akabori, S.; Ohtomi, M. Bull. Chem. Soc. J pn. 1975, 48, 2991). 
TABLE 2. Partitioning of Onium Salts in $\mathrm{ScCO}_{2} /$ Water

\begin{tabular}{|c|c|c|c|c|c|c|}
\hline \multirow[b]{2}{*}{ entry } & \multirow[b]{2}{*}{$\begin{array}{c}\text { PT- } \\
\text { catalysta }^{a}\end{array}$} & \multirow[b]{2}{*}{$\begin{array}{c}\text { reagent } \\
\mathbf{1}^{\mathrm{b}}\end{array}$} & \multicolumn{2}{|c|}{ aq phase $(25 \mathrm{~mL})$} & \multicolumn{2}{|c|}{$\%$ of $\mathrm{Br}^{-}$ion in } \\
\hline & & & alone & $\begin{array}{c}\text { added } \\
\mathrm{K}^{\mathrm{c}}(\mathrm{mol})\end{array}$ & $\begin{array}{c}\text { aq } \\
\text { phase }\end{array}$ & $\begin{array}{c}\text { Sc } \\
\text { phase }\end{array}$ \\
\hline 1 & $2 a$ & no & yes & none & 100 & - \\
\hline 2 & & yes & yes & none & 100 & - \\
\hline За & & no & yes & $\mathrm{X}=\mathrm{CO}_{3}{ }^{2-}$ & 100 & - \\
\hline $3 b$ & & yes & yes & $(0.12)$ & 82 & \\
\hline $4 a$ & & no & yes & $\mathrm{X}=\mathrm{NO}_{3}^{-}$ & 100 & - \\
\hline $4 b$ & & yes & yes & $(0.12)$ & 100 & - \\
\hline 5 & & yes & none & none & $\mathrm{ND}^{\mathrm{e}}$ & - \\
\hline $6 a$ & 2d & no & yes & $\mathrm{X}=\mathrm{CO}_{3}{ }^{2-}$ & 81 & - \\
\hline $6 b$ & & yes & yes & $(0.12)$ & 74 & - \\
\hline $7 a$ & & no & yes & $\mathrm{X}=\mathrm{NO}_{3}^{-}$ & 79 & - \\
\hline $7 b$ & & yes & yes & $(0.12)$ & 79 & - \\
\hline
\end{tabular}

a PT-catalysts $\left(\mathrm{Bu}_{4} \mathrm{P}^{+} \mathrm{Br}^{-}\right.$and $\left.\mathrm{C}_{16} \mathrm{H}_{33} \mathrm{PEt}_{3}{ }^{+} \mathrm{Br}^{-}\right)$were used in the same molar amount $(0.24 \mathrm{mmol}) .{ }^{b} \mathrm{n}$-Octyl mesylate was used for all experiments. ${ }^{\mathrm{C}} \mathrm{KX}\left(\mathrm{X}=\mathrm{CO}_{3}{ }^{2-}, \mathrm{NO}_{3}{ }^{-}\right)$added to the aqueous phase. ${ }^{d}$ Determined by titration with aq $\mathrm{AgNO}_{3}\left(5 \times 10^{-3} \mathrm{M}\right)$. e Not determined.

supercritical and the aqueous phase were withdrawn through calibrated loops and titrated for bromide with aq $\mathrm{AgNO}_{3}$ (see the Experimental Section). $\mathrm{CO}_{2}$ was then partially vented to 130 bar. n-Octyl mesylate $(3.0 \mathrm{~g}, 1.4$ $\times 10^{-2} \mathrm{~mol}$ ) was rapidly pumped into the autoclave with a stream of $\mathrm{CO}_{2}$ until the original pressure of 180 bar was reached. A second sample of the aqueous phase was collected and titrated, after stirring.

The same experiment was then repeated by loading initially the autoclave with (i) an aqueous solution of $\mathbf{2 a}$ $\left(9.6 \times 10^{-3} \mathrm{M}, 25 \mathrm{~mL}\right)$ containing either $\mathrm{K}_{2} \mathrm{CO}_{3}$ or $\mathrm{KNO}_{3}$ $(4.8 \mathrm{M})$ and (ii) the solid onium salt $(2 \mathrm{a}, 0.24 \mathrm{mmol})$.

Additionally, also the behavior of $\mathrm{n}_{-} \mathrm{C}_{16} \mathrm{H}_{33} \mathrm{PEt}_{3}{ }^{+} \mathrm{Br}^{-}$ (2d) was considered. Results are reported in Table 2.

It should be first noted that although $\mathrm{Bu}_{4} \mathrm{P}^{+} \mathrm{Br}^{-}$is soluble in n-octyl mesylate, and this in turn is soluble in $\mathrm{ScCO}_{2}$, not even traces of the salt are detected in supercritical phase, either in the presence or in the absence of water (entries 1, 2, and 5, respectively). ${ }^{20} \mathrm{At}$ $180 \mathrm{bar}$, the sulfonate ester is totally dissolved in $\mathrm{scCO}_{2}$ and clearly it does not act as a cosolvent for the PTcatalyst.

The addition of $\mathrm{K}_{2} \mathrm{CO}_{3}$ or $\mathrm{KNO}_{3}$ to the aqueous phase does not modify the partitioning (entries $3 a$ and $4 a$ ).

But if the reagent 1 and aqueous $\mathrm{K}_{2} \mathrm{CO}_{3}$ are added together, a salting-out effect is manifest (entry $3 b$ ). ${ }^{17}$ Though the PT-catalysts still does not dissolve in $\mathrm{SCCO}_{2}$, the phase transfer agent $\mathbf{2 a}$, which is mostly partitioned in water, can be accounted for by imagining that it forms a third liquid phase between the aqueous and the supercritical solvents. ${ }^{21}$

A similar situation reasonably holds during the reaction run in the presence of aq $\mathrm{KBr}$ (or $\mathrm{KI}$ or $\mathrm{KSCN}$ ). Under such conditions, however, a large excess of $\mathrm{KX}$ (X

(20) At atmospheric pressure and room temperature, the substrate $\mathbf{1}$ was able to dissolve an equimolar amount of the salt $\mathbf{2 a}$.

(21) The autoclave was equipped with sapphire windows for the visual observation of the mixture: also from this inspection, when the onium salt was used as a solid (entry 5, Table 2), it appeared totally immiscible in $\mathrm{SCCO}_{2}$. An analogous distribution was al ready reported by us when onium salts were in the presence of an apolar solvent and an aqueous phase. (a) Marques, C. A.; Selva, M.; Tundo, P. J . Org. Chem. 1994, 59, 3830. (b) Marques, C. A.; Selva, M.; Tundo, P.J . Org. Chem. 1995, 60, 2430. (c) Selva, M.; Perosa, A.; Tundo, P. J . Org. Chem. 1999, 64, 3934.
$=\mathrm{Br}, \mathrm{I}, \mathrm{SCN}$; all anions detectable by potentiometric titration) is present so that the direct titration of the bromide of the onium salt is not possible.

At room temperature and atmospheric pressure, compound $\mathbf{2 d}$ is miscible also with water and with the substrate 1. Table 2 shows that in the supercriticalaqueous biphase system, at 180 bar, a salt effect is possible with both aq $\mathrm{K}_{2} \mathrm{CO}_{3}$ and $\mathrm{KNO}_{3}$ (entries $6 \mathrm{a}$ and 7), and it is slightly increased by the addition of the reagent $\mathbf{1}$ (entry $6 \mathrm{~b}$ ). ${ }^{22}$ Though the catalyst $\mathbf{2 d}$ is not soluble in $\mathrm{CO}_{2}$ and as for compound $\mathbf{2 a}$, it may partly distribute as an immiscible third liquid phase.

\section{Conclusions}

This study indicates that nucleophilic displacement $\left(\mathrm{S}_{\mathrm{N}}\right)$ reactions under LSC-PTC conditions are controlled mainly by substrate concentration in the supercritical phase, which in turn is governed by the $\mathrm{CO}_{2}$ density at the operative pressure. In particular, we have defined a protocol for $\mathrm{S}_{\mathrm{N}}$ reactions under LSC-PTC conditions on the model substrate n-octylmesylate whereby $\mathrm{CO}_{2}$ pressure must be greater than 140 bar at $60-70{ }^{\circ} \mathrm{C}$, for a $\mathrm{CO}_{2}$ density of $0.55-0.65 \mathrm{~g} / \mathrm{mL}$.

Kinetic data indicate that supercritical $\mathrm{CO}_{2}$ is a good solvent for LSC-PTC and that its behavior, within limits, resembles that of $n$-heptane and toluene.

The $\mathrm{scCO}_{2}$ does not dissolve any measurable amount of phase-transfer catalysts. However, in the presence of n-octylmesylate and of a saline aqueous solution, a salt effect is observed, whereby some of the phase-transfer catalyst is not accounted for, either in the supercritical or aqueous phases. At this stage, there is no clear rationale for this behavior. Likely, with respect to a $\mathrm{scCO}_{2} /$ water system, different interfacial phenomena occur in the biphase formed by water and the binary mixture of $\mathrm{scCO}_{2}$-octylmesylate, which may either favor the formation of small droplets of PT-catalyst containing water or perhaps force part of the phosphonium salt to form a separate third liquid phase wherein the reaction takes place.

Future perspectives will be on the synthesis and use of onium salts with $\mathrm{CO}_{2}$-philic perfluorinated fragments. Moreover, the $\mathrm{pH}$-buffering effect of $\mathrm{CO}_{2}$ will also be investigated to tune the anion nucleophilicity.

\section{Experimental Section}

SAFETY WARNING: Operators of high-pressure equipment should take proper precautions to minimize the risks of personal injury. ${ }^{23}$

The silica-supported PT-agent $\mathbf{2 c}$ was synthesized and analyzed as previously described: ${ }^{24}$ the loading of the onium salts was of 0.30 mequiv per $\mathrm{g}$ of silica. $\mathrm{n}$-Octyl mesylate (1) was also prepared according to establ ished procedures. ${ }^{25}$ Before each reaction, compound $\mathbf{2 c}$ was dried by heating under vacuum at $60{ }^{\circ} \mathrm{C}$, overnight.

The LSc-reaction and the measures of concentration of $\mathbf{1}$ and octyl halides (Figures 2-3) in $\mathrm{scCO}_{2}$ were performed in

(22) Presently, there are no clear reasons for this unusual saltingout effect. Perhaps the presence of the sulfonate ester modifies the density/polarity of the sc-phase (and hence the nature of the interphase itself) so that onium salts may more easily be salted out.

(23) J essop, P. G.; I kariya, T.; Noyori, R. J . Am. Chem. Soc. 1996, 118,345

(24) (a) Tundo, P.; Venturello, P.J . Am. Chem. Soc. 1979, 101, 6606. (b) Tundo, P.; Venturello, P. J . Am. Chem. Soc. 1981, 103, 856

(25) Sekera, V. C.; Marvel, C. S. J . Am. Chem. Soc. 1933, 55, 345. 
stainless steel autoclaves of different volumes $(25,90$, and 150 $\mathrm{mL}$ ), all equipped with sapphire windows for the visual observation of the mixture, a manometer, and a thermocouple for the control of temperature. The $25-\mathrm{mL}$ cell was el ectrically heated, while $90-$ and $150-\mathrm{mL}$ autoclaves were thermostated by water-circulating jackets. The pressurization of all autoclaves with $\mathrm{CO}_{2}$ was performed with an automatic syringe pump (ISCO model $260 \mathrm{D}$ ).

Pressure Effect: Figure 1. A mixture of $\mathbf{1}$ (200 mg, 0.96 $\mathrm{mmol}$ ), the onium salt $\left(\mathrm{Bu}_{4} \mathrm{P}^{+} \mathrm{Br}^{-}\right)$or silica $\mathbf{2 c}$ (both $\mathbf{2 a}$ or $\mathbf{2 c}$ were in 0.05 molar equiv with respect to $\mathbf{1}$ ), and an aqueous solution of $\mathrm{KI}(0.5 \mathrm{~mL}, 4.8 \mathrm{M})$ was charged into a $25-\mathrm{mL}$ hastelloy cell, which was pressurized with $\mathrm{CO}_{2}$ (SFC/SFE grade) at approximately 30 bar. The autoclave was heated at the desired temperature $\left(50^{\circ} \mathrm{C}\right)$, while the reaction mixture was magnetically stirred. The final pressure ranging from 75 to 150 bar was reached by slowly adding the remaining $\mathrm{CO}_{2}$ to the reactor. The reaction was allowed to proceed for $5 \mathrm{~h}$; then, after cooling, $\mathrm{CO}_{2}$ was slowly vented by bubbling it into acetone $(5 \mathrm{~mL})$. The content of the cell was washed with additional acetone $(5 \mathrm{~mL})$, and the combined acetone solutions were analyzed by GC/MS fitted with a $30 \mathrm{~m}$ HP5MS chromatographic column.

The Concentration of n-Octyl Mesylate (1) and n-Octyl Halides in $\mathbf{s C C O}_{2}$ : Figures $\mathbf{2}$ and 3. I n a typical experiment, n-octyl mesylate (1, $1.2 \mathrm{~g}, 5.77 \mathrm{mmol})$ was charged in a 150$\mathrm{mL}$ autoclave, which was heated at $60^{\circ} \mathrm{C}$ and brought to the desired pressure of $\mathrm{CO}_{2}$ in the range of 80-150 bar. The mixture was kept under stirring at $750 \mathrm{rpm}$. After $30 \mathrm{~min}$, the agitation was stopped, and an aliquot of the mixture was withdrawn through a stainless steel calibrated loop of $1.12 \mathrm{~mL}$ fitted to the autoclave head. The loop was vented into acetone $(5 \mathrm{~mL})$ and washed thoroughly with additional acetone $(5 \mathrm{~mL})$. The combined acetone solutions were rotary-evaporated and the amount of the liquid residue of $\mathbf{1}$ was determined gravimetrically. The measure was repeated twice for each of the chosen pressures.

Additionally, the same experiment was repeated with a higher quantity of $\mathbf{1}(5 \mathrm{~g}, 0.024 \mathrm{mmol})$.

The above-described procedure also was used to measure the concentration of n-octyl halides $\left(\mathrm{C}_{8} \mathrm{H}_{17} \mathrm{X}, \mathrm{X}=\mathrm{Br}, \mathrm{I}\right)$, using $1.2 \mathrm{~g}$ of each compound.

The Kinetic Investigation: Figures $\mathbf{4}$ and $\mathbf{5}$ and Table 1. An aqueous solution of $K X\left(X=1, B r, N_{3}\right.$, and $S C N ; 7.5$ $\mathrm{mL}, 4.8 \mathrm{M})$ and $\mathrm{Bu}_{4} \mathrm{P}^{+} \mathrm{Br}^{-}(0.25 \mathrm{~g}, 0.74 \mathrm{mmol})$ was charged into an $90-\mathrm{mL}$ autoclave, heated at the desired temperature (60 or $70{ }^{\circ} \mathrm{C}$, see Figures 4 and 5), and pressurized with $\mathrm{CO}_{2}$ at 130 bar. The mixture was kept under magnetic stirring at $600 \mathrm{rpm}$. The autoclave was equipped with a calibrated loop $(1.12 \mathrm{~mL})$ by which $\mathrm{n}$-octyl mesylate $\left(1,3 \mathrm{~g}, 1.44 \times 10^{-2} \mathrm{mmol}\right)$ was pumped into the reactor with a stream of $\mathrm{CO}_{2}$ until the final pressure of 160 bar was reached. At intervals, through the same loop, aliquots of the reaction mixture were withdrawn, vented into acetone, and finally analyzed by GC and GC/MS. At the end of the reaction, the autoclave was cooled at room temperature, and its content was treated with diethyl ether $(25 \mathrm{~mL})$ and washed with water $(25 \mathrm{~mL})$. The organic extract was dried over $\mathrm{Na}_{2} \mathrm{SO}_{4}$ and filtered. After rotary evaporation, pure products $\left[\mathrm{n}-\mathrm{C}_{8} \mathrm{H}_{17} \mathrm{Br}\right.$ (3a); $\mathrm{n}-\mathrm{C}_{8} \mathrm{H}_{17}$ (3b); $n-\mathrm{C}_{8} \mathrm{H}_{17} \mathrm{~N}_{3}$ (3c); and n- $\mathrm{C}_{8} \mathrm{H}_{17} \mathrm{SCN}$ (3d)] were isolated.
The structures of compounds $\mathbf{3} \mathbf{a}, \mathbf{b}$ were confirmed by comparison with authentic commercial samples. The characterization of compound $3 \mathrm{c}$ was carried out by ${ }^{1} \mathrm{H}$ NMR and IR. Spectroscopic properties of compound $\mathbf{3 d}$ were in agreement with those al ready reported. ${ }^{26}$

n-Octyl Azide (3c). ${ }^{1} \mathrm{H}$ NMR $\left(\mathrm{CDCl}_{3}, 300 \mathrm{MHz}\right): \delta 3.27$ $\left(2 \mathrm{H}, \mathrm{t}, \mathrm{J}=7.0 \mathrm{~Hz}, \mathrm{~N}_{3} \mathrm{CH}_{2} \mathrm{CH}_{2}-\right), 1.62(2 \mathrm{H}, \mathrm{tt}, \mathrm{J}=7.0 \mathrm{~Hz}$, $\left.-\mathrm{CH}_{2} \mathrm{CH}_{2} \mathrm{CH}_{2} \mathrm{~N}_{3}\right), 1.5-1.2(10 \mathrm{H}, \mathrm{m}), 0.90(3 \mathrm{H}, \mathrm{t}$, J $=7.0 \mathrm{~Hz}$, $\left.\mathrm{CH}_{3} \mathrm{CH}_{2}-\right)$. IR $(\mathrm{KBr}), \mathrm{cm}^{-1}: 2960\left(\mathrm{C}-\mathrm{H}\right.$ asymm stretch $\left.\mathrm{CH}_{3}\right)$, $2920\left(\mathrm{C}-\mathrm{H}\right.$ asymm stretch $\left.\mathrm{CH}_{2}\right), 2870(\mathrm{C}-\mathrm{H}$ symm stretch $\left.\mathrm{CH}_{3}\right), 2850\left(\mathrm{C}-\mathrm{H}\right.$ symm. stretch $\left.\mathrm{CH}_{2}\right), 2095\left(\mathrm{~N}_{3}\right)$.

Experiments in Toluene and $\mathrm{n}$-Heptane: Table $1 . \mathrm{A}$ 200-mL, three-neck round-bottomed flask equipped with a thermostating jacket, a reflux condenser, an adapter for the withdrawal of samples, and a magnetic bar was loaded with a solution of n-octyl mesylate $\left(1,3 \mathrm{~g}, 1.44 \times 10^{-2} \mathrm{mmol}\right)$ in toluene or $\mathrm{n}$-heptane $(90 \mathrm{~mL})$. An aqueous solution of $\mathrm{KX}(\mathrm{X}$ $=\mathrm{I}, \mathrm{Br}, \mathrm{N}_{3}$, and $\left.\mathrm{SCN} ; 7.5 \mathrm{~mL}, 4.8 \mathrm{M}\right)$ and $\mathrm{Bu}_{4} \mathrm{P}^{+} \mathrm{Br}^{-}(0.25 \mathrm{~g}$, $0.74 \mathrm{mmol}$ ) was added and the mixture was kept under stirring. The flask was thermostated at $70{ }^{\circ} \mathrm{C}$. At intervals, samples of the reaction mixture were withdrawn and analyzed by $\mathrm{GC}$ and $\mathrm{GC} / \mathrm{MS}$.

Partitioning of Onium Salts in $\mathbf{S C C O}_{2}$ /water Biphase: Table 2. An aqueous solution of $\mathrm{Bu}_{4} \mathrm{P}^{+} \mathrm{Br}^{-}\left(9.6 \times 10^{-3} \mathrm{M}, 25\right.$ $\mathrm{mL}$ ) was charged into an $150-\mathrm{mL}$ autoclave and heated at 70 ${ }^{\circ} \mathrm{C}$, under stirring. The autoclave head was equipped with two calibrated loops [(a) and (b): $4.1 \mathrm{~mL}$ ], one of which (b) was also connected to $1 \frac{1}{8}$ in. tube dipping into the aqueous phase. The mixture was pressurized with $\mathrm{CO}_{2}$ at 180 bar. After 30 min, the agitation was stopped and samples of both the supercritical and the aqueous phases were withdrawn. The two loops were vented and thoroughly washed with a methanol/ water solution [1.1 v/v, $5 \mathrm{~mL}$, loop a: sc-phase] or simply water [5 mL, loop b: aq phase]. These samples were then analyzed separately by a potentiometric titrator with aq $\mathrm{AgNO}_{3}(5 \times$ $\left.10^{-3} \mathrm{M}\right)$.

$\mathrm{CO}_{2}$ was vented slowly until a pressure of 130 bar was reached. By using loop a, n-octyl mesylate (1, $3 \mathrm{~g}, 1.44 \times 10^{-2}$ $\mathrm{mmol}$ ) was charged into the autoclave with a stream of $\mathrm{CO}_{2}$ until the pressure of 180 bar was restored. Two more samples of the supercritical and the aqueous phases were withdrawn and analyzed through the above-described procedure.

The experiment was repeated with (i) an aqueous solution of $2 \mathrm{a}\left(9.6 \times 10^{-3} \mathrm{M}, 25 \mathrm{~mL}\right)$ containing either $\mathrm{K}_{2} \mathrm{CO}_{3}$ or $\mathrm{KNO}_{3}$ $(4.8 \mathrm{M})$ and (ii) the solid onium salt $(2 \mathrm{a}, 0.24 \mathrm{mmol})$. In this latter case, only loop a was used.

Both experiments also were carried with $n-\mathrm{C}_{16} \mathrm{H}_{33} \mathrm{PEt}_{3}{ }^{+} \mathrm{Br}^{-}$ (2d) either in aqueous solution $\left(9.6 \times 10^{-3} \mathrm{M}, 25 \mathrm{~mL}\right)$ or as a solid salt $(0.24 \mathrm{mmol})$.

Acknowledgment. MIUR (Italian Ministry of University and Scientific Research) and INCA (Interuniversity Consortium Chemistry for the E nvironment) are gratefully acknowledged for financial support.

\section{8} 65.

(26) I ranpoor, N.; I rouzabadi, H. F.; Shaterian, H. Synlett 2000, 1, 